Vemund Blomkvist

Euthalian Traditions 


\section{Texte und Untersuchungen zur Geschichte der altchristlichen Literatur}

Archiv für die Ausgabe der Griechischen Christlichen Schriftsteller der ersten Jahrhunderte

\section{(TU)}

Begründet von

O. von Gebhardt und A. von Harnack

Herausgegeben im Auftrag der

Berlin-Brandenburgischen Akademie der Wissenschaften von Christoph Markschies

Band 170 
Vemund Blomkvist

\title{
Euthalian Traditions
}

Text, Translation and Commentary

\author{
Including the Appendix \\ Parainesis as an Ancient Genre-Designation \\ by \\ David Hellholm and Vemund Blomkvist
}

De Gruyter 
Dieser Band wurde im Rahmen der gemeinsamen Forschungsförderung im Akademienprogramm mit Mitteln des Bundesministeriums für Forschung und der Senatsverwaltung für Wirtschaft, Technologie und Forschung des Landes Berlin erarbeitet.

\section{UNION}

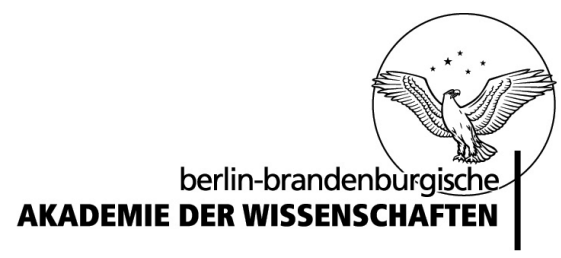

Gutachter dieses Bandes:

Hans-Gebhard Bethge und Christoph Markschies

Vemund Blomkvist. Born 1967. Dr. Philos. Senior Lecturer in Greek and New Testament Isagogics at the Faculty of Theology, University of Oslo.

This publication has been supported by the Research Council of Norway.

$$
\begin{aligned}
& \text { ISBN 978-3-11-029179-7 } \\
& \text { e-ISBN 978-3-11-029196-4 }
\end{aligned}
$$

ISSN 0082-3589

Library of Congress Cataloging-in-Publication Data

A CIP catalog record for this book has been applied for at the Library of Congress.

Bibliografische Information der Deutschen Nationalbibliothek

Die Deutsche Nationalbibliothek verzeichnet diese Publikation in der Deutschen Nationalbibliografie; detaillierte bibliografische Daten sind im Internet über http://dnb.dnb.de abrufbar.

(C) 2012 Walter de Gruyter GmbH, Berlin/Boston

Layout and typesetting: Progressus Consultant AB in Karlstad, Sweden

Druck: Hubert \& Co. GmbH \& Co. KG, Göttingen

$\infty$ Gedruckt auf säurefreiem Papier

Printed in Germany

www.degruyter.com 